Ratu Agung Ayu Dharmi Lestari Dkk, Struktur Cerita Rakyat Jayaprana-Layonsari dan Raden Sandubaya-Lala Seruni

\title{
Struktur Cerita Rakyat Jayaprana-Layonsari dan Raden Sandubaya- Lala Seruni: Sebuah Tinjauan Stukturalisme Levi-Stauss
}

\author{
Ratu Agung Ayu Dharmi Lestari, Halus Mandala, Ida Bagus Kade Gunayasa \\ Program Pascasarjana, Universitas Mataram \\ ratudharmi@gmail.com
}

\begin{abstract}
This research was conducted on two different regional folklore stories, namely Balinese folklore (Jayaprana-Layonsari) and Lombok folklore (Raden Sandubaya-Lala Seruni). This study aims to determine the comparison of the two folklore structures. The theory used is the theory of Levi-Strauss Structuralism. This research data was obtained through a library method by taking data from two folklore books entitled "Jayaprana" and "Raden Sandubaya and Lala Seruni" as well as through interview methods. The results of the study show that there are similarities and differences in the four structures of folktales that are compared. The equation is seen in geographical structure and cosmology. Geographical structure in the form of land and sea, while the cosmological structure in the form of the human world and the unseen world. Differences are seen in the techno-economic structure, Jayaprana-Layonsari folklore shows more variety in terms of people's livelihoods. In the sociology structure there are two aspects in common, one different aspect, and one aspect that has similarities as well as differences.

Keywords: Structure; folklore; Jayaprana-Layonsari; Sandubaya-Lala Seruni; Levi-Strauss.
\end{abstract}

\section{Intisari}

Penelitian kali ini dilakukan terhadap dua cerita rakyat berbeda daerah, yaitu cerita rakyat Bali (Jayaprana-Layonsari) dan cerita rakyat Lombok (Raden Sandubaya-Lala Seruni). Penelitian ini bertujuan untuk mengetahui perbandingan kedua struktur cerita rakyat tersebut. Teori yang digunakan adalah teori Strukturalisme Levi-Strauss. Data penelitian ini diperoleh melalui metode pustaka dengan mengambil data dari dua buku cerita rakyat berjudul "Jayaprana" dan "Raden Sandubaya dan Lala Seruni" serta melalui metode wawancara. Hasil penelitian menunjukkan bahwa terdapat persamaan dan perbedaan dalam empat struktur cerita rakyat yang diperbandingkan tersebut. Persamaan terlihat pada struktur geografis dan kosmologi. Struktur geografis berupa darat dan laut, sedangkan struktur kosmologi berupa dunia manusia dan dunia gaib. Perbedaan terlihat pada struktur techno-ekonomic, cerita rakyat Jayaprana-Layonsari menunjukkan lebih banyak variasi dalam hal mata pencaharian masyarakatnya. Pada struktur sosiologi terdapat dua aspek yang sama, satu aspek yang berbeda, dan satu aspek yang memiliki persamaan sekaligus juga perbedaan.

Kata kunci:Struktur; cerita rakyat; Jayaprana-Layonsari; Sandubaya-Lala Seruni; LeviStrauss.

\section{Pendahuluan}

Sastra tidak dapat terlepas dari kehidupan manusia, sastra hidup sebagai budaya dan bukti eksistensi manusia. Koentjaraningrat (1990) menjelaskan bahwa salah satu unsur 
kebudayaan adalah kesenian, dan salah satu jenis kesenian tersebut adalah seni sastra, baik dalam bentuk puisi maupun prosa, termasuk salah satunya cerita rakyat. Dengan demikian, sastra (cerita rakyat) dan masyarakat pendukungnya memiliki hubungan yang sangat erat. Di satu sisi, sastra (cerita rakyat) sebagai produk budaya, di sisi lain, sastra (cerita rakyat) menggambarkan budaya yang tengah berkembang saat itu.Hal tersebut senada dengan apa yang diungkapkan Hutomo (1991:3) mengenai ciri sastra lisan, salah satunya bahwa sastra lisan, dalam kasus ini cerita rakyat, menggambarkan budaya suatu masyarakat. Karena itu pula sastra lisan disebut juga sebagai fosil hidup.

Indonesia yang terkenal kaya akan budayanya, kaya akan suku bangsanya, tentunya memiliki banyak cerita rakyat yang tersebar di setiap daerah.Cerita rakyat tersebut menyimpan banyak nilai-nilai kehidupan, benar-salah, baik-buruk, dan pesan-pesan tersirat yang berguna dalam menjalani roda kehidupan. Cerita rakyat tersebut juga dibuat oleh nenek moyang dan diwariskan secara turun-temurun dari mulut ke mulut sebagai semacam pandangan hidup. Dananjaya (dalam Endraswara, 2013:202) memiliki istilah lain untuk menyebut kebudayaan kolektif yang diwariskan secara turun-temurun, yaitu folklor. Cerita rakyat termasuk pula bagian dari folklor, yaitu folklore lisan.

Dua di antara cerita rakyat yang terdapat di Indonesia adalah cerita rakyat Bali berjudul "Jayaprana-Layonsari" dan cerita rakyat Lombok berjudul "Raden SandubayaLala Seruni”. Kedua cerita rakyat tersebut memiliki keunikan tersendiri yang membuatnya menjadi objek yang menarik untuk diteliti. Keunikan tersebut berupa tema, tokoh dan penokohan, serta alur ceritanya yang hampir sama. Bahkan, akhir ceritanya yang tragispun sama. Tokoh utama yang merupakan sepasang suami istri berakhir dengan kematian, walaupun pada akhirnya diceritakan dapat bersatu kembali di dunia lain (alam gaib).

Persamaan yang begitu identik itu pun dapat dikatakan sebagai indikasi bahwa terdapat beberapa hal yang sama dalam struktur cerita rakyat tersebut yang mewakili struktur masyarakat pendukungnya. Karena pada dasarnya karya sastra lahir dari pengarang dan merupakan cerminan pemikirannya. Begitu pula cerita rakyat, lahir dari sebuah masyarakat dan merupakan cerminan pemikiran masyarakat tersebut. Untuk mengetahui struktur kedua cerita rakyat tersebut, maka digunakanlah teori Strukturalisme Levi-Strauss sebagai pisau bedahnya.

Levi-Strauss dalam penelitiannya lebih tertarik untuk menganalisis mitos dibandingkan jenis karya sastra yang lain. Menurut Levi-Strauss di sanalah nalar manusia 
memperoleh tempat ekspresinya yang paling bebas. Selanjutnya, Levi-Strauss (2005:281) juga mengatakan bahwa bagaimanapun bentuknya ketidaktahuan kita tentang bahasa dan kebudayaan dari masyarakat tempat mitos itu kita ambil, sebuah mitos tetap dipahami sebagai mitos oleh seluruh pembacanya di seluruh penjuru dunia. Mitos dalam konteks Strukturalisme Levi-Strauss tidak lain adalah dongeng (Ahimsa-Putra, 77:2001). Dongeng merupakan sebuah kisah atau ceritera yang lahir dari hasil imajinasi manusia, dari khayalan manusia, walaupun unsur-unsur khayalan tersebut berasal dari apa yang ada dalam kehidupan manusia sehari-hari (Ahimsa-Putra, 79:2001). Jadi menurut pengertiannya dapat dikatakan bahwa cerita rakyat dan dongeng yang oleh Levi-Strauss disebut mitos adalah hal yang sama.

Menurut Levi-Strauss ada beberapa tataran/struktur yang dapat dianalisis dalam sebuah dongeng/mitos, dalam hal ini cerita rakyat. Itu terlihat ketika ia mengkaji kisah "Asdiwal". Dalam analisisnya terhadap "Asdiwal”, Levi-Strauss membedakan empat tataran dalam dongeng yaitu: (1) tataran geografis; (2) tataran techno-economic; (3) tataran sosiologi; dan (4) tataran kosmologi (Ahimsa-Putra, 124:2001). Tataran geografis berkaitan dengan lingkungan cerita, yaitu wilayah atau tempat hidup dan lokasi perjalanan para tokoh cerita. Tataran techno-economic berkaitan dengan mata pencaharian masyarakat. Tataran sosiologis berkaitan dengan faktor sosiologis atau kemasyarakatan yang berwujud organisasi kemasyarakatan atau masalah-masalah kemasyarakatan lainnya. Tataran kosmologi berkaitan dengan hubungan ruang dan waktu dalam alam semesta, dapat berupa alam manusia (dunia fana), alam gaib, ataupun alam-alam lainnya yang terhubung dengan kehidupan para tokoh cerita. Dengan demikian kajian terhadap cerita rakyat "Jayaprana-Layonsari" dan Raden Sandubaya-Lala Seruni” akan difokuskan pada empat struktur tersebut.

Sementara itu, penelitian terhadap cerita rakyat dengan menggunakan teori strukturalisme Levi-Strauss sebagai pisau bedahnya sudah cukup sering dilakukan. Beberapa diantaranya yang pertama adalah artikel yang ditulis oleh Kiki Astrea berjudul "Analisis Strukturalisme Lévi-Strauss, Mitos, Simbol, dan Fungsi Legenda Goa Ngerong di Kecamatan Rengel Kabupaten Tuban bagi Masyarakat Sekitarnya (Kajian Folklor)" yang dimuat dalam prosiding Seminar Nasional Kesusastraan "Kearifan Nusantara: Perspektif Interdisiplin, Multidisiplin, dan Transdisiplin” halaman 1 - 11. Artikel tersebut membahas mengenai struktur legenda Goa Ngerong, mitos-mitos yang menyertainya, serta 
makna dari simbol-simbol yang terdapat pada legenda tersebut. Kedua, artikel berjudul "Cerita Rakyat Etnik Buru (Kajian Strukturalisme Levi-Strauss)" yang ditulis oleh Everhard Markiano Solissa dan dimuat dalam prosiding Seminar Nasional Kesusastraan "Kearifan Nusantara: Perspektif Interdisiplin, Multidisiplin, dan Transdisiplin" halaman 74 - 91.Artikel tersebut mengkaji struktur dari cerita rakyat etnik Buru ,Tit Fawu, dan menemukan 4 struktur di dalamnya, yaitu (1) struktur geografis menyangkut konsep Buru Utara dan Buru Selatan, (2) Struktut Tekno-Ekonomi berkaitan dengan mata pencaharian berkebun dan berburu, (3) Struktur sosiologis menyangkut hubungan kakak adik yang horizontal bukan vertical, (4) Struktur Kosmologi berkaitan dengan pandangan orang buru tentang kematian dan dunia nyata. Ketiga, artikel berjudul "Cerita Rakyat Masyarakat Mamasa: Kajian Struktural Antropologi Claude Levi Strauss" yang ditulis oleh Nurul Setyorini. Artikel ini membahas tentang 4 struktur cerita rakyat Mamasa, berupa struktur ekologi, struktur sosiologis, struktur ekonomi, dan struktur kosmologi. Selain itu diungkapkan pula tentang logika cerita rakyat masyarakat Mamasa yang menyatakan bahwa pertama terdapat konsepi tentang kehidupan yang trikotomis menyangkut konsep kesetiaan dan amanah, dan kedua terdapat konsepsi tentang alam gaib bahwa dalam alam semesta terdapat tipe diadik, yakni dunia alam gaib dan dunia manusia.

\section{Metode Penelitian}

Metode yang digunakan dalam penelitian ini adalah metode deskriptif kualitatif. Metode kualitatif menurut Moleong (2017:9) yaitu berupa pengamatan, wawancara, atau penelaahan dokumen. Selanjutnya menurut Moleong (2017:11) dalam analisis deskriptif data yang dikumpulkan adalah berupa kata-kata, gambar, dan bukan angka-angka.

Data yang digunakan pada penelitian ini berupa unit-unit konstituen mite/cerita rakyat yang oleh Levi-Strauss disebut sebagai mitem (mythem). Yang dimaksud dengan unit-unit konstituen atau mitem ini ialah frase, atau kalimat-minimal yang - karena posisinya di dalam konteks - memberikan hubungan penting antara berbagai aspek, kejadian, dan tokoh dalam kisah (Paz, 2013:18).

Untuk memperoleh data berupa mitem-mitem tersebut, maka digunakan metode pustaka dan wawancara dalam proses pengumpulan data. Teknik pustaka yakni mempergunakan sumber-sumber tertulis untuk memperoleh data (Subroto, 1992:24). Studi pustaka dilakukan terhadap dua buku cerita rakyat yang menjadi objek penelitian ini. Buku 
Ratu Agung Ayu Dharmi Lestari Dkk, Struktur Cerita Rakyat Jayaprana-Layonsari dan Raden Sandubaya-Lala Seruni

pertama adalah buku cerita rakyat Bali yang berjudul "Jayaprana" yang dikeluarkan oleh Pusat Pembinaan dan Pengembangan Bahasa Departemen Pendidikan Nasional tahun 2000. Buku kedua adalah buku cerita rakyat Lombok yang berjudul "Raden Sandubaya dan Lala Seruni" yang dikeluarkan oleh Pusat Pembinaan dan Pengembangan Bahasa Departemen Pendidikan Nasional tahun 1994.

Metode kedua yang digunakan adalah metode wawancara, dalam hal ini wawancara terstruktur. Wawancara terstruktur adalah wawancara yang pewawancaranya menetapkan sendiri masalah dan pertanyaan-pertanyaan yang akan diajukan (Moleong, 2017:190). Untuk mendapatkan hasil wawancara yang maksimal, maka penentuan kriteria informan harus diperhatikan. Oleh karena itu, penentuan informan dilakukan dengan teknik purposive sampling. Informan yang diperoleh melalui teknik purposive samplingdalam penelitian ini berjumlah dua orang. Pertama adalah Jero Mangku Ketut Kasih yang merupakan pemangku di Pura Jayaprana yang terletak di Teluk Terima, Singaraja Bali. Wawancara dilakukan untuk memperoleh informasi yang dibutuhkan berkaitan dengan cerita rakyat Jayaprana-Layonsari. Informan kedua adalah Lalu Napsiah, S.S. yang bekerja sebagai Fungsional Pamong Budaya Madya menangani naskah-naskah di Museum NTB. Wawancara dilakukan untuk memperoleh informasi mengenai cerita rakyat Raden Sandubaya-Lala Seruni.

Selanjutnya data yang telah terkumpul melalui metode pustaka dan wawancara tersebut, yang berupa mitem-mitem, kemudian akan dianalisis menggunakan teori LeviStrauss. Adapun langkah-langkah analisis tersebut adalah sebagai berikut:

a. Menyusun miteme-miteme tersebut secara sintagmatik dan paradigmatik untuk melihat hubungan satu dengan yang lainnya. Hubungan sintagmatik adalah hubungan yang bersifat horizontal sedangkan hubungan paradigmatik adalah hubungan yang bersifat vertikal.

b. Miteme-miteme pada masing-masing cerita rakyat yang telah tersusun tersebut kemudian dibandingkan guna mengetahui persamaan atau perbedaan yang terdapat pada cerita rakyat Bali Jayaprana-Layonsari dan cerita rakyat Lombok Raden Sandubaya-Lala Seruni.

c. Menemukan struktur dari kedua cerita rakyat tersebut berdasarkan miteme-miteme yang tersusun secara sintagmatik dan paradigmatik. Struktur tersebut menyangkut struktur gografis, struktur techno-economic, struktur sosiologis, dan struktur 
Ratu Agung Ayu Dharmi Lestari Dkk, Struktur Cerita Rakyat Jayaprana-Layonsari dan Raden Sandubaya-Lala Seruni

kosmologi yang memiliki hubungan bersifat kosokbali (oppositional), relatif, atau negative.

\section{Hasil dan Pembahasan}

Dalam analisisnya terhadap Asdiwal, Levi-Strauss membedakan empat tataran dalam dongeng (Ahimsa-Putra, 124:2001) yaitu: (1) tataran geografis; (2) tataran technoeconomic; (3) tataran sosiologi; dan (4) tataran kosmologi. Oleh karena itu pada pembahasan ini ada empattataran/struktur yang akan dikaji berkaitan dengan cerita rakyat Jayaprana-Layonsari dan Raden Sandubaya-Lala Seruni, yaitu struktur geografis , struktur techno-economic, struktur sosiologi, dan struktur kosmologi. Berikut ini akan dibahas satu per satu struktur kedua cerita rakyat tersebut.

\section{1) Struktur Geografis}

Struktur geografis cerita rakyat Jayaprana-Layonsari dan Raden Sandubaya-Lala Seruni secara garis besar ada dua yaitu darat dan laut, karena latar yang tampak pada kedua cerita rakyat tersebut adalah menyangkut kehidupan di darat dan di laut. Jika divisualkan akan tampak pada skema berikut.

\section{a. Cerita Rakyat Jayaprana dan Layonsari}

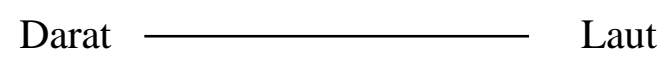

\section{b. Cerita Rakyat Raden Sandubaya dan Lala Seruni}

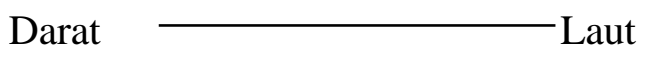

Kehidupan di darat dibuktikan dengan berbagai latar kedua cerita rakyat tersebut seperti di hutan, di pasar, di kerajaan, di sawah/ladang. Sedangkan kehidupan laut dibuktikan dengan latar Teluk Terima untuk cerita Jayaprana-Layonsari dan Pantai Menanga Baris untuk cerita Raden Sandubaya-Lala Seruni.

\section{2) StrukturTechno-Economic}


Ratu Agung Ayu Dharmi Lestari Dkk, Struktur Cerita Rakyat Jayaprana-Layonsari dan Raden Sandubaya-Lala Seruni

Struktur techno-economic berkaitan dengan mata pencaharian masyarakat. Dalam cerita Jayaprana-Layonsari dan Raden Sandubaya-Lala Seruni terdapat struktur technoeconomic yang dapat divisualisasikan sebagai berikut.

\section{a. Cerita Rakyat Jayaprana dan Layonsari}

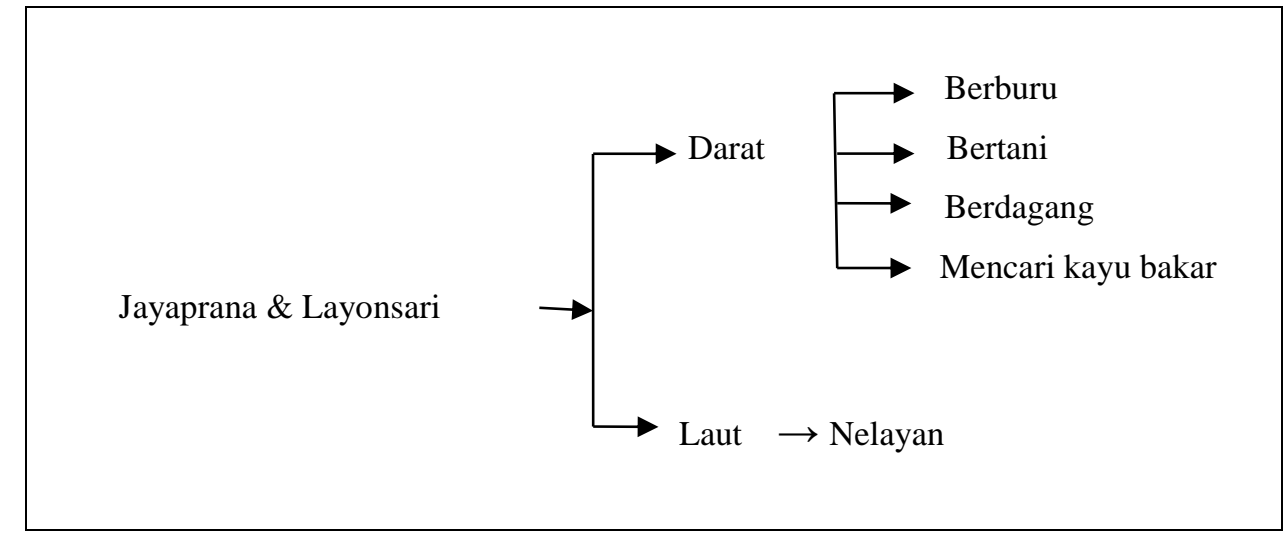

\section{b. Cerita Rakyat Raden Sandubaya dan Lala Seruni}

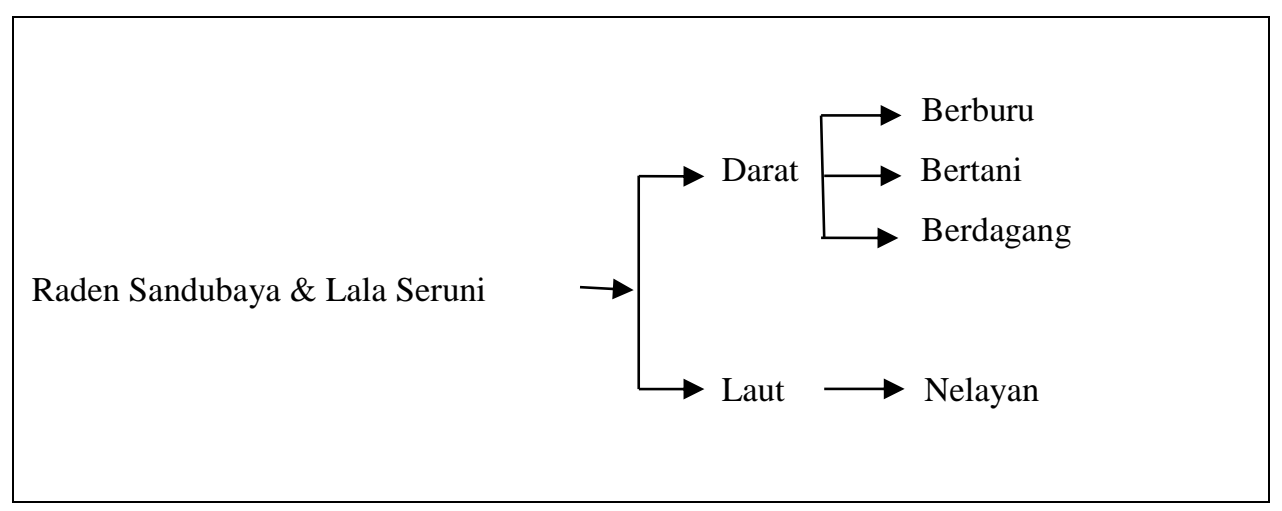

Pada kedua skema tersebut terlihat jelas bahwa berdasarkan struktur geografi darat dan laut, terdapat struktur techno-economicyang mengikutinya. Terdapat sedikit perbedaan pada struktur techno-economickedua cerita rakyat tersebut. Pada cerita JayapranaLayonsari, mata pencaharian masyarakatnya meliputi berburu, bertani, berdagang, mencari kayu bakar, dan sebagai nelayan. Sedangkan pada cerita Raden Sandubaya-Lala Seruni yang tampak adalah berburu, bertani, dan berdagang. Berburu dalam hal ini tidak selalu untuk memperoleh buruan untuk kemudian dijual, tetapi terkadang hanya untuk kegemaran dan untuk konsumsi sendiri seperti halnya perburuan yang dilakukan oleh raja dan prajuritnya. 
Ratu Agung Ayu Dharmi Lestari Dkk, Struktur Cerita Rakyat Jayaprana-Layonsari dan Raden Sandubaya-Lala Seruni

\section{3) Struktur Sosiologis}

Struktur sosiologis menyangkut kehidupan sosial yang mengikat para tokohnya. Aspek yang menyangkut kehidupan sosial tokohnya meliputi, pertama, status sosial yang mereka miliki, menyakut posisi tokoh dalam masyarakat. Aspek kedua menyangkut status mereka dalam sebuah pranata sosila berupa keluarga. Aspek ketiga menyangkut hubungan mereka dengan pasangannya, kaitannya dengan kesetiaan. Aspek keempat adalah sistem pemerintahan yang mengatur kehidupan sosial masyarakatnya. Jika divisualkan akan terlihat pada skema berikut ini

\section{a. Status Sosial Tokoh Utama}

\section{Cerita Jayaprana dan Layonsari}

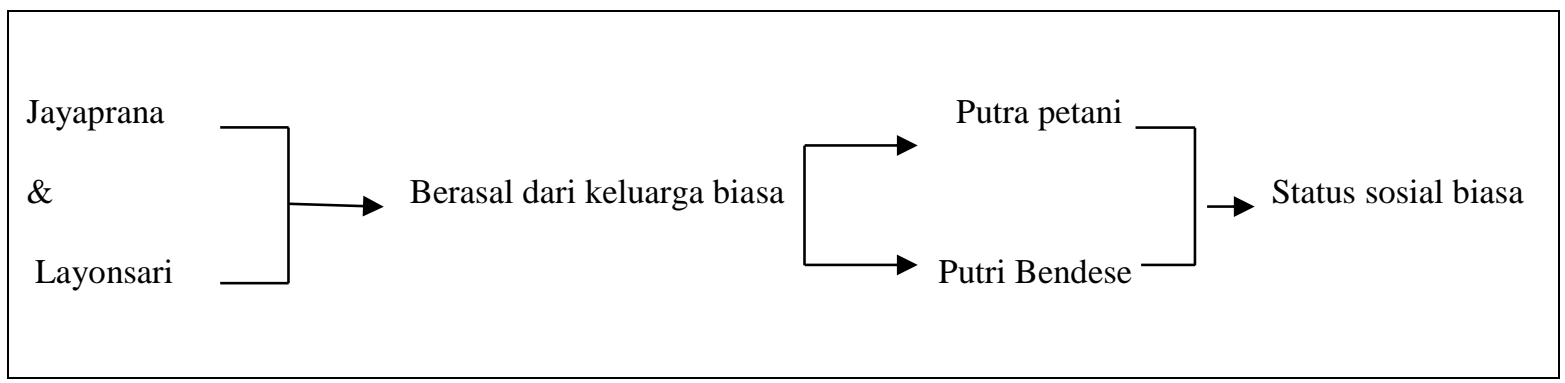

\section{Cerita Raden Sandubaya dan Lala Seruni}

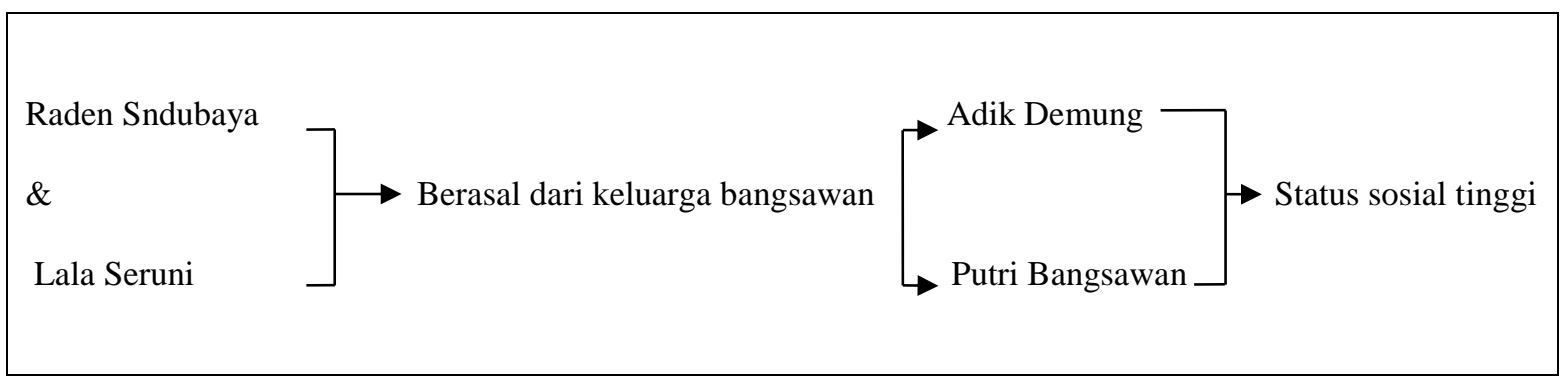

Status sosial tokoh utama, baik pria maupun wanita pada kedua cerita rakyat tersebut sangat berbeda. Tokoh utama pria dan wanita pada cerita Jayaprana \& Layonsari berasal dari latar belakang masyarakat biasa atau kebanyakan, sedangkan pada cerita Raden Sandubaya dan Lala Seruni tokoh utama pria dan wanitanya berasal dari keluarga terhormat, dari keluarga bangsawan. Sebenarnya sangat mudah untuk mengenali latar belakang tokoh utama cerita Bali dan Lombok tersebut, karena kedua kebudayaan tersebut memiliki sistem penamaan yang membedakan status sosial masyarakatnya. Nama I Nyoman dan Ni Nyoman yang disandang Jayaprana dan Layonsari menandakan ia berasal 
Ratu Agung Ayu Dharmi Lestari Dkk, Struktur Cerita Rakyat Jayaprana-Layonsari dan Raden Sandubaya-Lala Seruni

dari masyarakat biasa, sedangkan title Raden dan Lala adalah nama yang hanya dimiliki oleh bangsawan (bangsawan Lombok).

\section{b. Status Kekeluargaan}

\section{Cerita Jayaprana dan Layonsari}

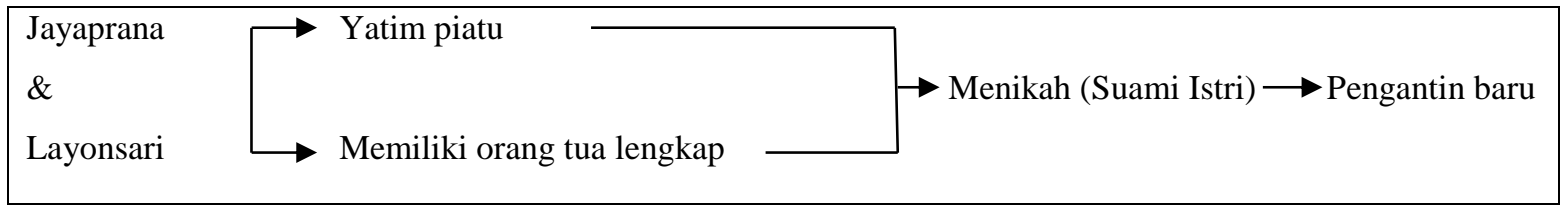

\section{Cerita Raden Sandubaya dan Lala Seruni}

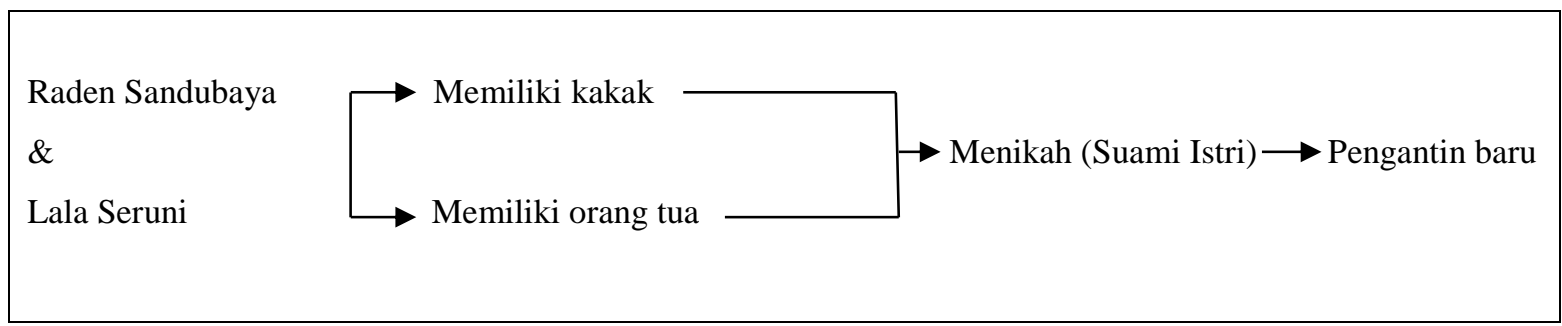

Status kekeluargaan tokoh utama kedua cerita tersebut sama, yaitu sudah menikah, merupakan pasangan suami istri, dan adalah pengantin baru. Yang membedakan adalah Jayaprana adalah seorang yatim piatu yang tak memiliki satu pun keluarga yang tersisa setelah wabah menyerang desa, sedangkan Raden Sandubaya masih memiliki seorang kakak yang melindunginya. Untuk tokoh utama wanita sama-sama berasal dari keluarga yang lengkap, memiliki ayah dan ibu.

\section{c. Konsep Kesetiaan Tokoh Pria}

\section{Cerita Jayaprana dan Layonsari}

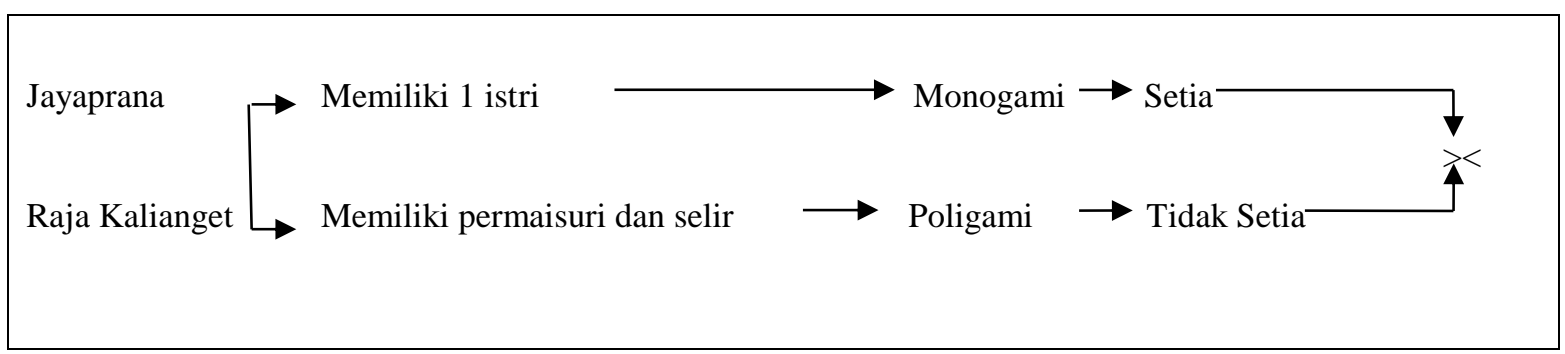

\section{Cerita Raden Sandubaya dan Lala Seruni}

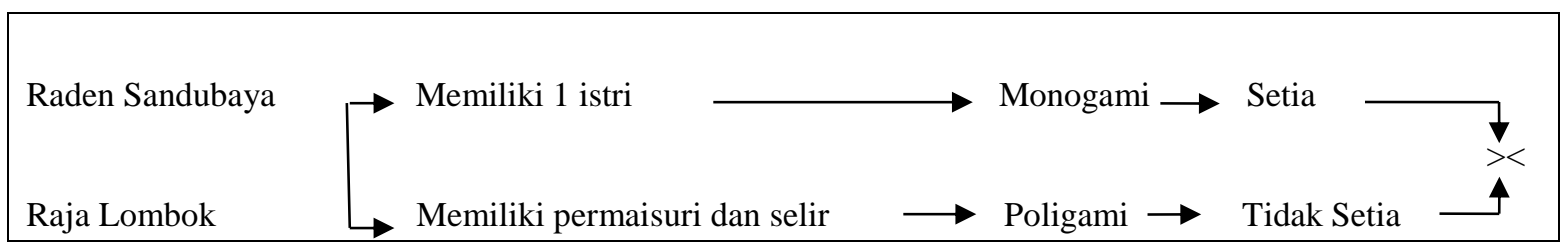


Tokoh utama protagonis dan antagonis pada kedua cerita rakyat beroposisi dalam hal kesetiaan. Pada cerita Jayaprana dan Layonsari, Jayaprana yang merupakan tokoh utama protagonis memiliki satu istri yaitu Layonsari. Ia menjalankan pernikahan monogami dan setia pada istrinya. Sedangkan Raja Bali sebagai tokoh antagonis memiliki permaisuri dan selir dan hendak pula menjadikan Layonsari sebagai istrinya. Hal tersebut menandakan bahwa ia menganut pernikahan poligami dan tidak setia pada istrinya (istri pertama).

Begitu pula pada cerita Raden Sandubaya dan Lala Seruni. Raden Sandubaya sebagai tokoh utama pria hannya memiliki satu istri, yaitu Lala Seruni. Ia menganut pernikahan monogami dan setia pada istrinya. Berbanding terbalik dengan Raja Lombok yang dikisahkan memiliki banyak selir dan juga berniat menikahi Lala Seruni.

Tokoh utama protagonis, baik pada cerita rakyat Jayaprana dan Layonsari maupun pada cerita Raden Sandubaya dan Lala Seruni merupakan pasangan yang setia, sedangkan tokoh antagonis pada kedua cerita tersebut sama-sama tidak setia pada pasangannya.

\section{d. Sistem Pemerintahan}

\section{Cerita Jayaprana dan Layonsari}

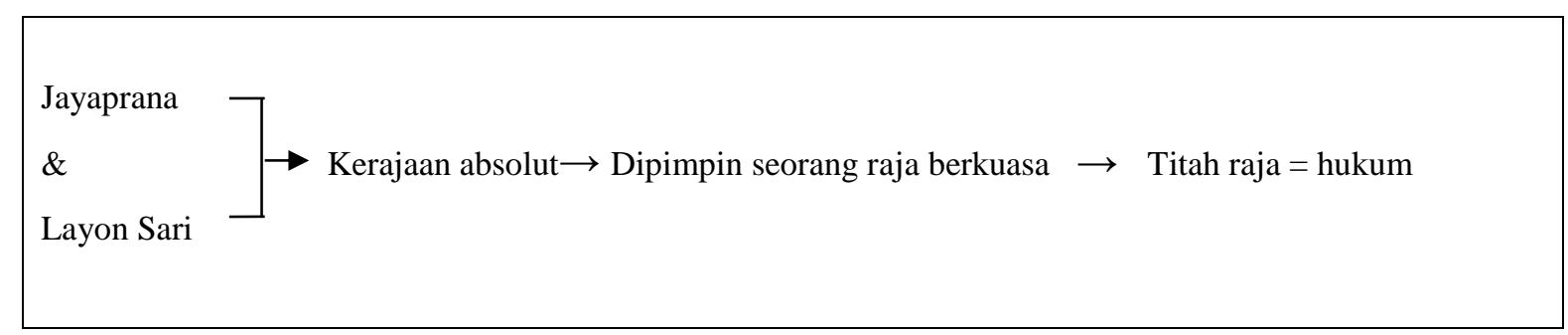

\section{Cerita Raden Sandubaya dan Lala Seruni}

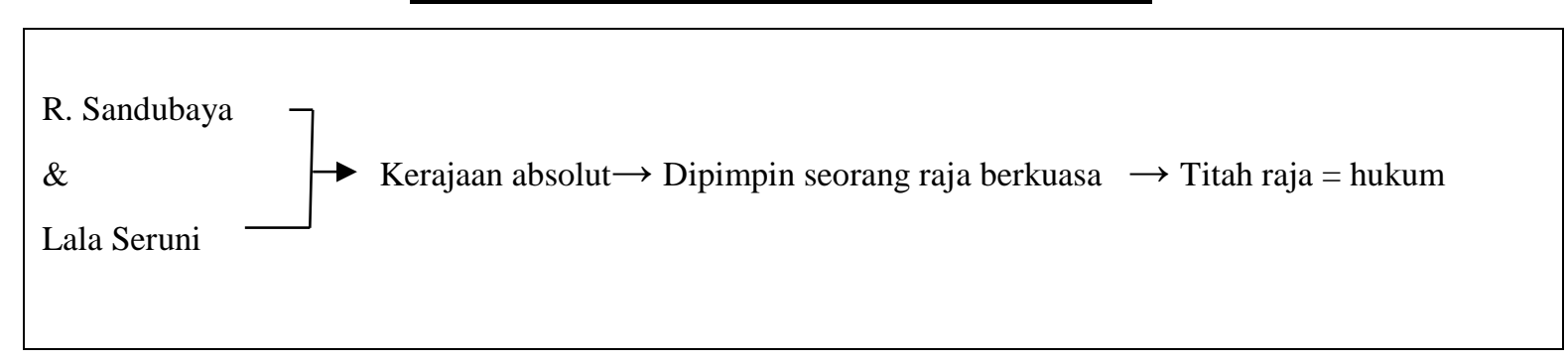

Sistem pemerintahan pada kedua cerita rakyat tersebut sama-sama bersistem kerajaan yang bersifat absolute, di mana raja memiliki kuasa penuh terhadap kehidupan rakyatnya yang ditandai dengan titah raja yang dianggap sebagai hukum. Siapapun tak boleh melanggar/menentang titah raja, sekalipun itu berarti mereka harus mati. 


\section{4) Struktur Kosmologi}

\section{Cerita Jayaprana dan Layonsari}

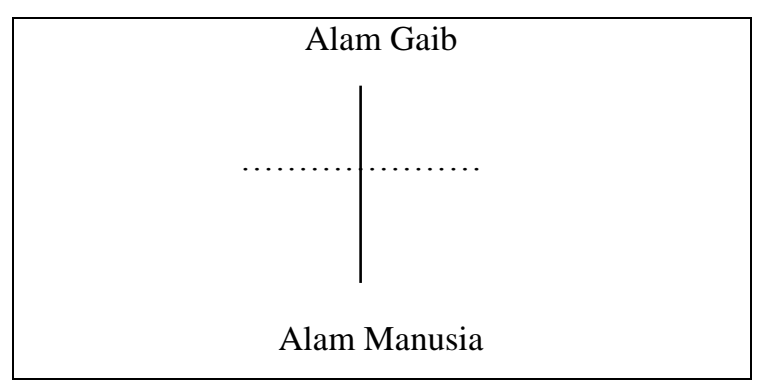

\section{Cerita Raden Sandubaya dan Lala Seruni}

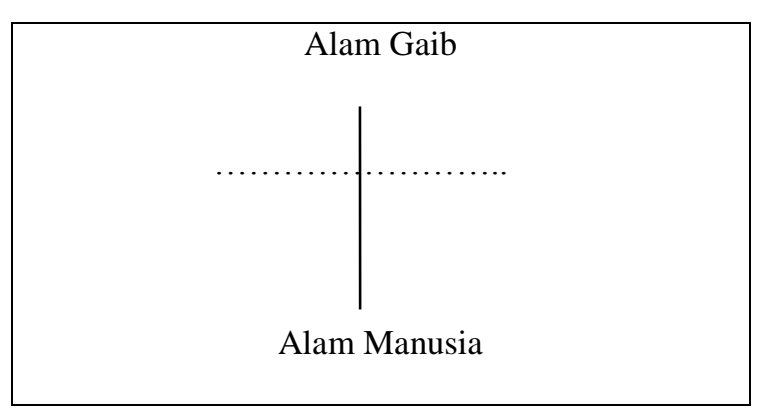

Struktur kosmologi pada kedua cerita rakyat tersebut menampilkan dua dunia berbeda, yaitu dinia nyata tempat para manusia, dan dunia gaib tempat bersemayamnya para dewa dan arwah serta makhluk gaib lainnya. Kedudukan kedua dinia tersebut tidaklah sama atau horizontal, melainkan vertikal. Dunia gaib dinilai merupakan dunia kekal yang keberadaannya lebih tinggi dari dunia manusia. Jayaprana dan Layonsari ketika telah meninggal dipercaya rohnya bersemayam di Pura Jayaprana dalam kekekalan. Di cerita Jayaprana juga disebutkan bahwa raja bermohon pada Dewa. Jadi jelas, bahwa dunia gaib dinilai memiliki keberadaan lebih tinggi dari alam manusia. Begitu pula pada cerita Raden Sandubaya dan Lala Seruni. Diceritakan setelah meninggal,roh Raden Sandubaya menjemput Lala Seruni di Pantai Menanga Baris dan membawa istrinya ke alamnya, alam para arwah yang kekal.

\section{Simpulan}

Penelitian ini menghasilkan kesimpulan bahwa cerita rakyat Bali dan Lombok, JayapranaLayonsari dan Raden-Sandubaya Lala Seruni memiliki lebih banyak persamaan dibandingkan perbedaan dalam struktur ceritanya. Cerita Jayaprana-Layonsari dan Raden Sandubaya-Lala Seruni memiliki struktur geografis yang sama yaitu darat dan laut. Dalam 
Ratu Agung Ayu Dharmi Lestari Dkk, Struktur Cerita Rakyat Jayaprana-Layonsari dan Raden Sandubaya-Lala Seruni

struktur techno-economic kedua cerita rakyat tersebut memiliki sedikit perbedaan dalam hal jenis mata pencaharian masyarakat, cerita rakyat Jayaprana-Layonsari memiliki jenis mata pencaharian yang lebih beragam. Sementara itu dalam struktur sosiologi dalam beberapa aspek terdapat kesamaan dan ada pula perbedaan. Persamaannya terletak pada konsep kesetiaan tokoh dan sistem pemerintahan, sedangkan perbedaannya terletak pada status sosial tokoh. Sementara itu pada status kekeluargaan terdapat aspek yang sama dan ada pula aspek yang berbeda. Struktur terakhir atau struktur kosmologi dari kedua cerita rakyat tersebut memiliki persamaan, yaitu bahwa terdapat dua dunia, dunia manusia dan dunia ghaib.

\section{Daftar Pustaka}

Ahimsa-Putra, Heddy Shri. 2001. Strukturalisme: Mitos dan Karya Sastra. Yogyakarta: Galang Press.

Ali, Slamet Riyadi. 1994. Raden Sandubaya dan Lala Seruni. Jakarta: Pusat Pembinaan dan Pengembangan Bahasa Departemen Pendidikan Nasional.

Astrea, Kiki. 2017. Analisis Strukturalisme Levi-Strauss, Mitos, Simbol, dan Fungsi Legenda Goa Ngerong di Kecamatan Rengel Kabupaten Tuban bagi Masyarakat Sekitarnya (Kajian Folklor). Prosiding Seminar Nasional Kesusastraan "Kearifan Nusantara : Perspektif Interdisiplin, Multidisiplin, dan Transdisiplin”: halaman 1 -11 .

Atisah. 2000. Jayaprana. Jakarta: Pusat Pembinaan dan Pengembangan Bahasa Departemen Pendidikan Nasional.

Endraswara, Suwardi. 2013. Metodologi Penelitian Sastra: Epistemologi, Model, Teori, dan Aplikasi. Yogyakarta: Caps.

Hutomo, Suripan Sadi. 1991. Mutiara yang Terlupakan: Pengantar Sudi Sastra Lisan. Surabaya: HISKI.

Koentjaraningrat. 1990. Kebudayaan, Mentalitas dan Pembangunan. Jakarta: Gramedia Pustaka Utama.

Lévi-Strauss, Claude. 2005. Antropologi Struktural. Ninik Rochani Sjams (penerjemah). 2005. Yogyakarta: Kreasi Wacana.

Moleong, Lexy J. 2017. Metodologi Penelitian Kualitatif. Bandung: Remaja Rosdakarya.

Paz, Octavio. 2013. Lévi-Stauss: Empu Antropologi Struktural. Yogyakarta: LKiS.

Setyorini, Nurul. 2017. Cerita Rakyat Masyarakat Mamasa: Kajian Struktural Antropologi Claude Levi Strauss. (online). (Ejurnal.umpwr.ac.id), diakses tanggal 6 Juli 2019.

Solissa, Everhard Markiano. 2017. Cerita Rakyat Etnik Buru (Kajian Strukturalisme LeviStrauss). Prosiding Seminar Nasional Kesusastraan "Kearifan Nusantara : Perspektif Interdisiplin, Multidisiplin, dan Transdisiplin”, halaman 74 - 91.

Subroto. 1992. Penelitian Kualitatif. Jakarta: Raja Grafindo Persada. 